\title{
The Metal Catalyst Influences the Kinetics and Mechanisms of MS2 Inactivation in Fenton-like Systems
}

\author{
Jessica I. Nieto-Juarez and Tamar Kohn*
}

\begin{abstract}
Human enteric viruses are frequent microbial contaminants of surface water and groundwater. Waterborne viruses can be effectively inactivated by oxidants, such as those generated in Fenton-like systems. However, the mechanisms by which this inactivation occurs are not understood. Here we investigated how two Fenton-like systems, $\mathrm{Cu} / \mathrm{H}_{2} \mathrm{O}_{2}$ and $\mathrm{Fe} / \mathrm{H}_{2} \mathrm{O}_{2}$ /light, affect the infectivity and structural integrity of MS2 coliphage, a frequently used surrogate for human enteric viruses. The extent of MS2 genome and capsid protein degradation was evaluated by quantitative PCR and protein mass spectrometry, and was related to the observed level of inactivation. Even though inactivation in both systems occurred via the same oxidant, hydroxyl radical, the contributions of genome and capsid protein degradation to inactivation differed. Inactivation in the $\mathrm{Cu} /$ $\mathrm{H}_{2} \mathrm{O}_{2}$ system was rapid and involved both genome and protein damage. In contrast, inactivation in $\mathrm{Fe} / \mathrm{H}_{2} \mathrm{O}_{2} /$ light proceeded at a slower rate and encompassed solely genome damage. Our findings demonstrate that not only the oxidant, but also its source, the metal catalyst, determines the inactivation kinetics and mechanism in Fenton-like systems. This work provides the first evidence of the impact of the metal catalyst on virus inactivation in Fenton-like systems.
\end{abstract}

Keywords: Disinfection · Fenton · Inactivation mechanisms · Protein mass spectrometry · Waterborne virus

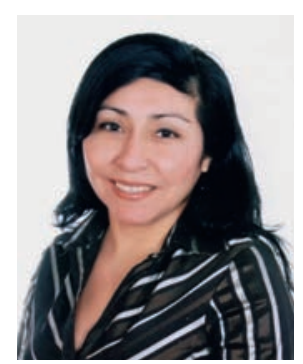

Jessica Ivana Nieto Juarez obtained a Diploma in Chemistry from the National University of Engineering in Lima, Peru, and a MSc in Chemistry from the University of Concepcion, Chile. She received a Swiss government scholarship to conduct research in the Advanced Oxidation Processes Group of Prof. Cesar Pulgarin (EPFL), and later joined the Environmental Chemistry Laboratory at EPFL (Prof. Tamar Kohn) for her doctoral work in Environmental Engineering. Since 2016 she is a professor in the Faculty of Chemical and Textile Engineering at the National University of Engineering in Peru. Her research focuses on sustainable methods for water treatment by AOPs.

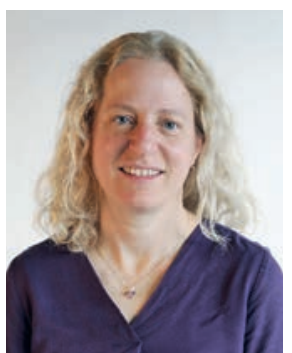

Tamar Kohn studied Environmental Sciences at ETH Zurich. In 2000 she joined the group of Prof. Lynn Roberts at Johns Hopkins University (USA), where she conducted research on the remediation of chlorinate solvents in groundwater. After completing her $\mathrm{PhD}$ degree in 2004, she performed postdoctoral studies in the group of Prof. Kara Nelson at UC Berkeley. In 2007 she joined EPFL, first as an Assistant professor and since 2013 as an Associate professor, where she directs the Laboratory of Environmental Chemistry. Her research focuses on the removal of chemical and microbiological contaminants from water and wastewater.

\section{Introduction}

The disinfection of drinking water, and in some countries of wastewater, is an important step in preventing the transmission of waterborne diseases such as poliomyelitis or hepatitis. Water disinfection is typically performed by treatment with an oxidizing chemical, such as free chlorine $(\mathrm{HOCl})$ or ozone, or by physical methods such as the irradiation by UVC light. These methods, while effective, each have disadvantages, such as a high energy consumption, or the formation of hazardous disinfection by-products. Therefore, much research has been conducted in recent years to devise alternative disinfection strategies that rely on more energy-efficient and environmentally sustainable disinfection methods.

Over the past decade, Fenton-like processes have been explored as alternative methods for water disinfection. The most attention has been dedicated to the photo-Fenton system, in which ferric iron is photo-reduced to ferrous iron, which subsequently reacts with hydrogen peroxide $\left(\mathrm{H}_{2} \mathrm{O}_{2}\right)$ to generate oxidants. ${ }^{[1-4]}$ Fenton-like systems using other transition metals or iron (hydr) oxide minerals as catalyst to generate oxidants have also been explored.[5-11] Fenton-like systems can successfully inactivate various pathogens, including viruses. ${ }^{[5,8-10,12]}$ Hydroxyl radicals $\left(\mathrm{HO}^{\bullet}\right)$ formed by the Fenton process, have been implicated as inactivating agents in these processes, ${ }^{[9]}$ though their mechanism of action is not understood. Specifically, it is unclear which virus constituents (genome and proteins) are most efficiently targeted.

$\mathrm{HO}^{\bullet}$ radicals are known to be reactive toward the different viral building blocks. $\mathrm{HO}^{\bullet}$ radicals can oxidize all amino acids, though tryptophan, tyrosine, histidine and cysteine are the most suscep- 
tible. ${ }^{[13]} \mathrm{HO}^{\bullet}$ is also reactive toward all nucleotides that make up the viral genome. ${ }^{[14]}$ Previous studies conducted on viruses have shown that $\mathrm{HO}^{\bullet}$ generated by $\mathrm{TiO}_{2}$ photocatalytic disinfection induced genome damage in RNA and DNA coliphages, though protein degradation was not considered. ${ }^{[15,16]}$ To our knowledge, damage to virus components in Fenton-like systems has not been investigated.

Our previous work has shown that Fenton-like systems (Fe/ $\mathrm{H}_{2} \mathrm{O}_{2}$ /light, and $\mathrm{Cu} / \mathrm{H}_{2} \mathrm{O}_{2}$ systems) efficiently inactivate bacteriophage $\mathrm{MS}^{[9]}$ (Fig. 1). The aim of this work was to investigate chemical degradation of the components of MS2 during treatment in these Fenton-like systems, and to link the observed degradation to inactivation. To this end, we combined Fenton chemistry with protein mass spectrometry and traditional tools of environmental virology (virus culturing to measure infectivity; quantitative polymerase chain reaction (qPCR) to measure genome integrity). MS2 is a frequently used model organism for human enteric viruses. It is a non-enveloped coliphage that consists of an RNA genome (single-stranded RNA, 3569 nucleotides) surrounded by 180 copies of a capsid protein $(\mathrm{CP} ; 13.7 \mathrm{kDa}$, 129 amino acids). In addition, the virion contains a single copy of an assembly protein (A protein, $43.9 \mathrm{kDa}, 339$ amino acids). Inactivation and damage to the MS2 genome and capsid proteins was studied in both Fenton-like systems, and the patterns of damage were compared to elucidate the role of the oxidant and the metal catalysts in inactivation.

\section{Materials and Methods}

MS2 phages were inactivated in two Fenton-like systems: one containing $\mathrm{Cu} / \mathrm{H}_{2} \mathrm{O}_{2}$, and one composed of $\mathrm{Fe} / \mathrm{H}_{2} \mathrm{O}_{2}$ irradiated by simulated sunlight. Samples were periodically taken and analyzed for remaining MS2 infectivity, as well as genome and protein integrity. Damage to different segments of the viral genome was quantified by qPCR. Individual losses of the capsid protein fragments were determined by protein mass spectrometry (Matrix-assisted laser desorption ionization time-of-flight mass spectrometry; MALDI-TOF-MS).

\section{Reagents and Organisms}

\section{Reagents}

Copper sulfate $\left(\mathrm{CuSO}_{4} .5 \mathrm{H}_{2} \mathrm{O}\right)$, hydrogen peroxide $\left(\mathrm{H}_{2} \mathrm{O}_{2}\right.$, $30 \%)$, EDTA, catalase (2000-5000 units $\mathrm{mg}^{-1}$ protein), and $\alpha$-cyano-4-hydroxycinnamic acid were purchased from SigmaAldrich (St. Louis, Missouri). Ferric chloride $\left(\mathrm{FeCl}_{3} \cdot 6 \mathrm{H}_{2} \mathrm{O}\right)$, sodium bicarbonate $\left(\mathrm{NaHCO}_{3}, 99+\%\right), \mathrm{NaCl}(99+\%), \mathrm{CaCl}_{2}$ $(99+\%), \mathrm{NaH}_{2} \mathrm{PO}_{4}(99+\%)$, trifluoroacetic acid (TFA), acetoni-

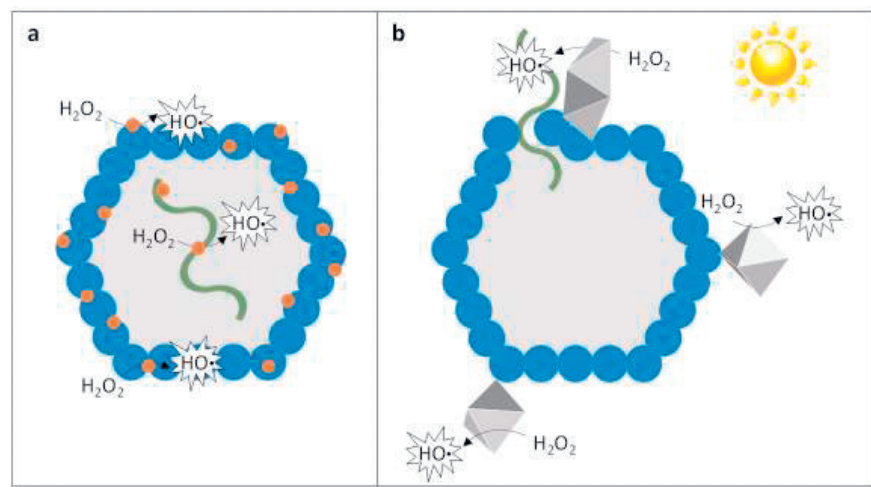

Fig. 1. Schematic illustration of MS2 inactivation in the two Fenton-like systems considered herein. Viral proteins are shown in blue; the viral genome is shown in green. In the $\mathrm{Cu} / \mathrm{H}_{2} \mathrm{O}_{2}$ system (a), MS2 is inactivated by $\mathrm{HO}^{\bullet}$ produced by dissolved $\mathrm{Cu}$ species, which can densely cover the virion. In the $\mathrm{FeH}_{2} \mathrm{O}_{2}$ /light system (b), MS2 is inactivated by $\mathrm{HO}^{\bullet}$ produced by colloidal iron, which may denature the viral proteins. trile (ACN, HPLC grade) were obtained from Acrõs Organics (Geel, Belgium). Trypsin and chymotrypsin were purchased from Worthington Biochemical Corporation (Lakewood, NJ).

\section{Organisms}

MS2 coliphage (DSMZ 13767) and its bacterial host E. coli (DSMZ 5695) were purchased from the German collection of microorganisms and cell cultures (DSMZ, Braunschweig, Germany). The propagation and purification of MS2 was performed as previously described. ${ }^{[17]}$ The infective MS2 phage concentrations were enumerated by the double-layer agar method and measured in plaque-forming units per $\mathrm{ml}\left(\mathrm{PFU} \mathrm{ml} \mathrm{m}^{-1}\right)$. The MS2 stock solution had a concentration of $10^{14} \mathrm{PFU} \mathrm{ml}^{-1}$ and was stored in dilution buffer (DB; $5 \mathrm{mmol} \mathrm{l}^{-1} \mathrm{NaH}_{2} \mathrm{PO}_{4}, 10 \mathrm{mmol} \mathrm{l}^{-1} \mathrm{NaCl}, \mathrm{pH} 7.4$ ) at $4{ }^{\circ} \mathrm{C}$.

A ${ }^{15} \mathrm{~N}$-labeled stock of $\mathrm{MS} 2$ was produced as the internal standard for quantitative protein mass spectrometric analyses. ${ }^{15} \mathrm{~N}$-labeled MS2 was propagated and purified as described previously, ${ }^{[18]}$ using E. coli (ATTC 15597; LGC Standards, Molsheim, France) as the host. The ${ }^{15} \mathrm{~N}$-labeled MS2 stock solution had a concentration of $10^{13} \mathrm{PFU} \mathrm{ml} \mathrm{l}^{-1}$ and was stored in $\mathrm{DB}$ at $4{ }^{\circ} \mathrm{C}$.

\section{Inactivation Experiments}

Experiments were carried out in sacrificial glass reactors $(50$ $\mathrm{ml}$ ), with an initial infective MS2 concentration of $10^{10} \mathrm{PFU} \mathrm{ml}{ }^{-1}$ (detection limit for the protein mass measurements) in $20 \mathrm{ml}$ of carbonate-buffered saline (CBS; $0.1 \mathrm{mmol} \mathrm{l}^{-1} \mathrm{NaHCO}_{3}, 15 \mathrm{mmol}$ $1^{-1} \mathrm{NaCl}$ ) at $\mathrm{pH}$ 6.9. $\mathrm{Cu}$ (II) or $\mathrm{Fe}(\mathrm{III})$ were added to the reactors from stock solutions $\left(1 \mathrm{mmol} \mathrm{l}^{-1} \mathrm{CuSO}_{4}\right.$ or $\mathrm{FeCl}_{3}$ ) to obtain a final concentration of $10 \mu \mathrm{mol} \mathrm{l}^{-1}$. $\mathrm{H}_{2} \mathrm{O}_{2}$ was added from a $25 \mathrm{mmol} \mathrm{l}^{-1}$ stock solution to a final concentration of $50 \mu \mathrm{mol} \mathrm{l}^{-1}$. EDTA $(2 \mu \mathrm{mol}$ $1^{-1}$ ) was added to complex any trace metals, which have shown to catalyze Fenton-like processes. ${ }^{[9]}$ This EDTA concentration did not cause virus inactivation. The solutions were stirred at $400 \mathrm{rpm}$ on a multi-position stir plate. To obtain different levels of inactivation, $500 \mu \mathrm{L}$ of catalase (500 units $\mathrm{ml}^{-1}$ ) were added to sacrificial reactors at different times to scavenge the remaining $\mathrm{H}_{2} \mathrm{O}_{2}$ and halt the Fenton-like reactions. $\mathrm{H}_{2} \mathrm{O}_{2}$-free control samples were also evaluated. After catalase addition, sample aliquots were withdrawn from reactors for virus quantification by culturing. The remainder of the solution was used for genome and capsid protein analysis as described below. All experiments were performed in triplicate.

For photo-Fenton experiments, $\mathrm{Fe} / \mathrm{H}_{2} \mathrm{O}_{2}$ solutions were irradiated using a solar simulator (ABET Technologies, Sun 2000) with $1000 \mathrm{~W}$ Xe lamp, an air mass 1.5 filter and UVB cut-off filter. The UVB cut-off filter was used to avoid confounding effects arising from direct genome damage induced by UVB light. The resulting light spectrum has been previously reported. ${ }^{[8]}$ The total irradiance in the visible spectrum was $320 \mathrm{~W} \mathrm{~m}^{-2}$. The sample temperature was controlled by placing the reactors in a cooled water bath at $20 \pm 2{ }^{\circ} \mathrm{C}$. Dark control experiments were conducted in reactors covered with aluminium foil.

\section{Virus Aggregation}

Virus aggregation was measured by dynamic light scattering (Malvern Instruments, Nano ZS) as previously described. ${ }^{[19]}$ Aggregation measurements were conducted for the same solution conditions as used in the inactivation experiments.

\section{Measurement of Genome Damage by qPCR}

Quantitative polymerase chain reaction (qPCR) was used to quantify and localize the genome damage of MS2 upon inactivation. $200 \mu \mathrm{L}$ of samples were withdrawn from the reactors for the immediate extraction of virus genomes as previously described. ${ }^{[17]}$ Damage to six different genome segments of approximately 300 nucleotides was quantified using a RotorGene 3000 quantitative PCR platform (Corbett Life Science, Sidney, Australia). Jointly, the six segments covered approximately $50 \%$ of the entire ge- 
nome. The exact location of the segments within the genome, as well as the primers used, are described in Table 1. Each segment was first reverse transcribed and then amplified using the one step SYBR PrimeScript RT-PCR kit according the manufacturer's procedure (Takara Bio Inc., Shiga, Japan). The qPCR protocols are described in detail elsewhere. ${ }^{[17]}$ SYBR green was used as the fluorescent probe for all segments.

Damage to the entire genome was extrapolated from the measured damage to the six segments as described previously.[20] Briefly, the proportion of intact whole genomes $\left(\mathrm{N} / \mathrm{N}_{\mathrm{o}}\right)$ in the sample at any level of inactivation can be calculated as:

$$
\frac{N}{N_{0}}=\prod_{i=1}^{6}\left(\frac{n_{i}}{n_{i, 0}}\right)^{\frac{\text { total genome length }}{\text { length of } 6 \text { genome segments }}}
$$

where $\prod_{i=1}^{6}\left(\frac{n_{i}}{n_{i}}\right)$ corresponds to the product of the intact proportions of each of the six individual genome segments $\left(n_{i}\right)$ considered. The total genome length corresponds to the MS2 genome size (3569 nucleotides) and the length of six genome segments is the sum of all genome segment sizes shown in Table 1.

The extent of damage to each genome segment was assessed before and after inactivation. The inactivation levels studied were between $2 \log (99 \%)$ and $7 \log (99.99999 \%)$ for $\mathrm{Cu} / \mathrm{H}_{2} \mathrm{O}_{2}$ system and between $1 \log (90 \%)$ and $7 \log$ for the $\mathrm{Fe} / \mathrm{H}_{2} \mathrm{O}_{2} /$ light system.

\section{Measurement of Capsid Protein Damage by MALDI- TOF-MS}

Protein analysis was conducted on the same samples as genome analysis. Protein mass spectrometry was used to identify the regions of the MS2 capsid protein that were most susceptible to damage. After inactivation, $20 \mu \mathrm{l}$ of ${ }^{15} \mathrm{~N}$-labeled MS2 was added to each reactor as an internal standard for the quantification of protein damage. The ratio of initial native MS2 to labeled MS2 was 1:1. The capsid protein was denatured, alkylated and digested by two protease enzymes (trypsin or chymotrypsin) into small peptides as previously described. ${ }^{[18]}$ The MS2 capsid protein sequence and the peptides generated by the digestion are shown in Tables 2 and 3, respectively. Jointly, the peptides resulting from digestion by the two protease enzymes yielded a $98 \%$ coverage of the capsid protein.

Calibration curves for each peptide were obtained by analyzing six different ratios of native to labeled MS2 (ratio range $0.2-1.2$ ). The standards were denatured, alkylated and digested in the same way as the samples. The intact fraction of each peptide upon inactivation was determined by comparing the peak ratio of the native to labeled peptide in a sample to the ratios measured in the calibration curve.

Peptide analyses were carried out in positive ion linear mode MALDI-TOF-MS (ABI 4800; Applied Biosystems, Rotkreuz, Switzerland). The MALDI matrix used was $7 \mathrm{mg} \mathrm{ml}^{-1}$ of $\alpha$-cyano4-hydroxy-cinnamic acid solution diluted in 50\% ACN and 50\% TFA $(0.1 \%)$ as the solvent. The ratio between matrix and sample was 10 to 1 . These mixtures of each sample were placed on a MALDI plate by quadruped and were air-dried. MALDI spectra were analyzed with Applied Biosystems Data Explorer Software.

\section{Results \\ Inactivation Kinetics}

MS2 was readily inactivated in both the $\mathrm{Cu} / \mathrm{H}_{2} \mathrm{O}_{2}$ and the $\mathrm{Fe} /$ $\mathrm{H}_{2} \mathrm{O}_{2}$ /light systems (Fig. 2). Virus inactivation followed (pseudo-) first-order kinetics for both disinfection systems. In the $\mathrm{H}_{2} \mathrm{O}_{2}$-free control samples, a decrease in infectious MS2 of approximately $90 \%$ (1 log loss) in $15 \mathrm{~min}$ and $99 \%$ (2 log loss) in 30 min was observed for $\mathrm{Cu}$ and $\mathrm{Fe}$ systems, respectively. Metal-free $\mathrm{H}_{2} \mathrm{O}_{2}$ samples have previously been shown to not cause inactivation at the concentrations studied herein. ${ }^{[9]}$

Table 1. Primer sets, segment position and segment sizes used for the quantification of MS2 genome damage. nt = nucleotide.

\begin{tabular}{|c|c|c|c|c|}
\hline Segment number ${ }^{\mathrm{a}}$ & Primer direction & Primer sequence ( $5^{\prime}$ to $\left.3^{\prime}\right)$ & Genome position & Segment size (nt) \\
\hline 2 & $\begin{array}{l}\text { Forward } \\
\text { Reverse }\end{array}$ & $\begin{array}{l}\text { AAGGTGCCTACAAGCGAAGT } \\
\text { TTCGTTTAGGGCAAGGTAGC }\end{array}$ & 344 to 678 & 335 \\
\hline 3 & $\begin{array}{l}\text { Forward } \\
\text { Reverse }\end{array}$ & $\begin{array}{l}\text { CCGCTACCTTGCCCTAAAC } \\
\text { GACGACAACCATGCCAAAC }\end{array}$ & 657 to 959 & 303 \\
\hline 6 & $\begin{array}{l}\text { Forward } \\
\text { Reverse }\end{array}$ & $\begin{array}{l}\text { CCTAAAGTGGCAACCCAGAC } \\
\text { AAAGATCGCGAGGAAGATCA }\end{array}$ & 1530 to 1818 & 289 \\
\hline 7 & $\begin{array}{l}\text { Forward } \\
\text { Reverse }\end{array}$ & $\begin{array}{l}\text { CGCGATCTTTCTCTCGAAAT } \\
\text { GACGATCGGTAGCCAGAGAG }\end{array}$ & 1809 to 2125 & 317 \\
\hline 10 & $\begin{array}{l}\text { Forward } \\
\text { Reverse }\end{array}$ & $\begin{array}{l}\text { ATAGTCAAAGCGACCCAAATC } \\
\text { GGCGTGGATCTGACATACCT }\end{array}$ & 2724 to 3033 & 310 \\
\hline 12 & $\begin{array}{l}\text { Forward } \\
\text { Reverse }\end{array}$ & $\begin{array}{l}\text { GAAATCACCGACAGCATGAA } \\
\text { AATCCCGGGTCCTCTCTTTA }\end{array}$ & 3285 to 3528 & 240 \\
\hline
\end{tabular}

${ }^{a}$ Numbering corresponds to that in Pecson et al. ${ }^{[17]}$ 
Table 3. Peptides generated by the protease enzymes of MS2 capsid protein

\begin{tabular}{|l|l|l|}
\hline $\mathbf{m} / \mathbf{z}$ & Position & Sequence \\
\hline Chymotrypsin & & \\
\hline 814.373 & $1-7$ & ASNFTQF \\
\hline 1761.865 & $8-25$ & VLVDNGGTGDVTVAPSNF \\
\hline 746.347 & $26-32$ & ANGVAEW \\
\hline 1112.533 & $33-42$ & ISSNSRSQAY \\
\hline 2492.412 & $59-82$ & TIKVEVPKVATQTVGGVELP VAAW \\
\hline 1687.865 & $113-129$ & KDGNPIPSAIAANSGIY \\
\hline Trypsin & & \\
\hline 596.304 & $39-43$ & SQAYK \\
\hline 664.345 & $44-49$ & VTCSVR \\
\hline 790.380 & $50-56$ & QSSAQNR \\
\hline 1753.960 & $67-83$ & VATQTVGGVELPVAAWR \\
\hline 2671.314 & $84-106$ & SYLNMELTIPIFATNSDCEL IVK \\
\hline 760.438 & $107-113$ & AMQGLLK \\
\hline
\end{tabular}

\section{Genome Damage}

Two aspects of genome damage were assessed: the distribution of damage across the genome, and the extent of genome damage as a function of inactivation. Damage was assessed before treatment and at two levels of inactivation, as well in the relevant $\mathrm{H}_{2} \mathrm{O}_{2}$-free control samples.

In the control samples without $\mathrm{H}_{2} \mathrm{O}_{2}$, all genome segments remained intact in both systems investigated. However, a decrease in the qPCR signal indicative of genome damage was measured at each level of inactivation (Fig. 3). At the lower levels of inactivation ( 1 or $2 \log$ ), a similar, heterogeneous pattern of damage was observed in both systems. The most affected genome segments were segments 2 and 3, whereas little or no damage was observed in the other four segments. At higher levels of inactivation $(7 \mathrm{log})$, the differences in degradation between the segments was less ap-

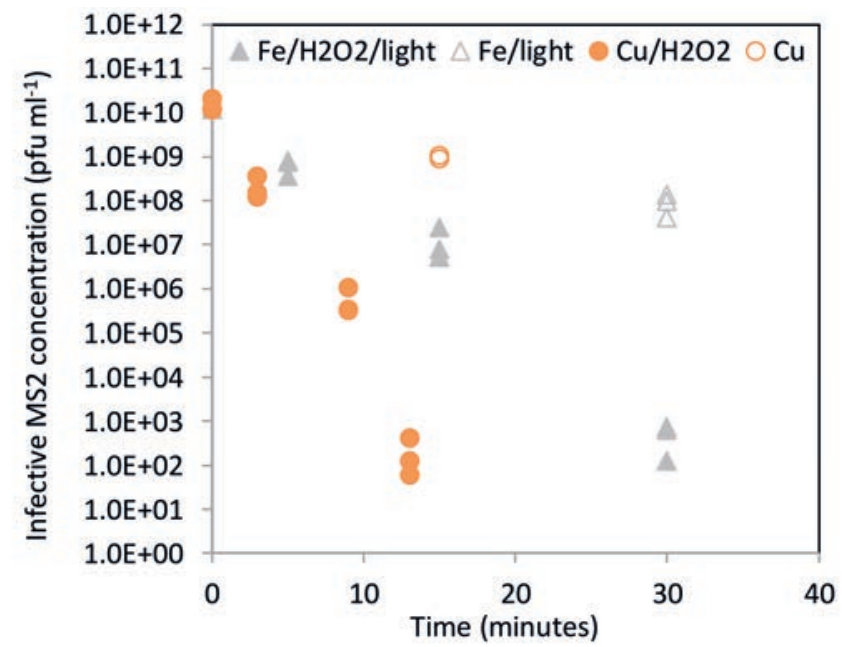

Fig. 2. MS2 inactivation by $\mathrm{Cu} / \mathrm{H}_{2} \mathrm{O}_{2}$ and $\mathrm{Fe} / \mathrm{H}_{2} \mathrm{O}_{2}$ /light systems. Orange circles show inactivation in the $\mathrm{Cu} / \mathrm{H}_{2} \mathrm{O}_{2}$ system, and grey triangles in the $\mathrm{Fe} / \mathrm{H}_{2} \mathrm{O}_{2}$ /light system. Empty symbols indicate the $\mathrm{H}_{2} \mathrm{O}_{2}$-free controls. Initial infective MS2 concentration $=10^{10} \mathrm{PFU} \mathrm{ml}{ }^{-1}$, metals $=10 \mu \mathrm{mol} \mathrm{I}^{-1}$, $\mathrm{H}_{2} \mathrm{O}_{2}=50 \mu \mathrm{M}, \mathrm{EDTA}=\mu \mathrm{mol} \mathrm{I} \mathrm{I}^{-1}$. parent. Furthermore, at $7 \log$ inactivation, genome damage in the $\mathrm{Fe} / \mathrm{H}_{2} \mathrm{O}_{2} /$ light exceeded that in the $\mathrm{Cu} / \mathrm{H}_{2} \mathrm{O}_{2}$.

To evaluate the extent of damage across the whole genome as a function of inactivation, the proportions of intact, whole genome $\left(\mathrm{N} / \mathrm{N}_{0}\right)$ and remaining infectivity $\left(\mathrm{C} / \mathrm{C}_{0}\right)$ were compared (Fig. 4). Hereby, $\mathrm{C} / \mathrm{C}_{0}$ was assessed by culturing, whereas $\mathrm{N} / \mathrm{N}_{0}$ was determined by extrapolating qPCR data, using Eqn. (1). For the $\mathrm{Cu} /$ $\mathrm{H}_{2} \mathrm{O}_{2}$ system, the extent of genome integrity loss was approximately equal to that of infectivity loss (Fig. 4a). In contrast, in the $\mathrm{Fe} / \mathrm{H}_{2} \mathrm{O}_{2}$ /light system, the extent of genome damage exceeded that of inactivation, in particular at high levels of inactivation (Fig. $4 b)$.

\section{Capsid Protein Damage}

As for genome damage, the extent of capsid protein damage incurred at two levels of inactivation were evaluated for the $\mathrm{Cu} / \mathrm{H}_{2} \mathrm{O}_{2}$ and $\mathrm{Fe} / \mathrm{H}_{2} \mathrm{O}_{2}$ /light systems, respectively. We assessed whether the inactivation by these treatments leads to protein degradation, and if so, which protein segments (peptides) are most susceptible.

The pattern of damage significantly differed between the two systems studied (Fig. 5): in the $\mathrm{Cu}$ system, the $\mathrm{H}_{2} \mathrm{O}_{2}$-free control sample showed a homogeneous loss in intact peptide concentration of roughly $20 \%$ (Fig. 5a). Upon addition of $\mathrm{H}_{2} \mathrm{O}_{2}$, an increasing loss in intact peptide concentration was observed for all peptides at $2 \log$ and $7 \log$ of inactivation. Notably, some peptides were affected to a greater extent, namely those found at $\mathrm{m} / \mathrm{z}$ 1761 (position 8-25), 1754 (position 67-83) and 2671 (position 84-106). In the Fe-based system, a heterogeneous decrease in peptide signal was observed in the $\mathrm{H}_{2} \mathrm{O}_{2}$-free control (Fig. 5b). In contrast to the $\mathrm{Cu}$ system, most peptides did not degrade further upon addition of $\mathrm{H}_{2} \mathrm{O}_{2}$. Only selected peptides (e.g. m/z 184, position 1-7) exhibited a measurable decay after $7 \log$ inactivation compared to the $\mathrm{H}_{2} \mathrm{O}_{2}$-free control.

\section{Discussion}

To assess the utility of Fenton-like systems for virus disinfection, it is important to understand the inactivation mechanisms involved. Here, virus inactivation was evaluated by means of investigating the inactivation kinetics, along with the accompanying 

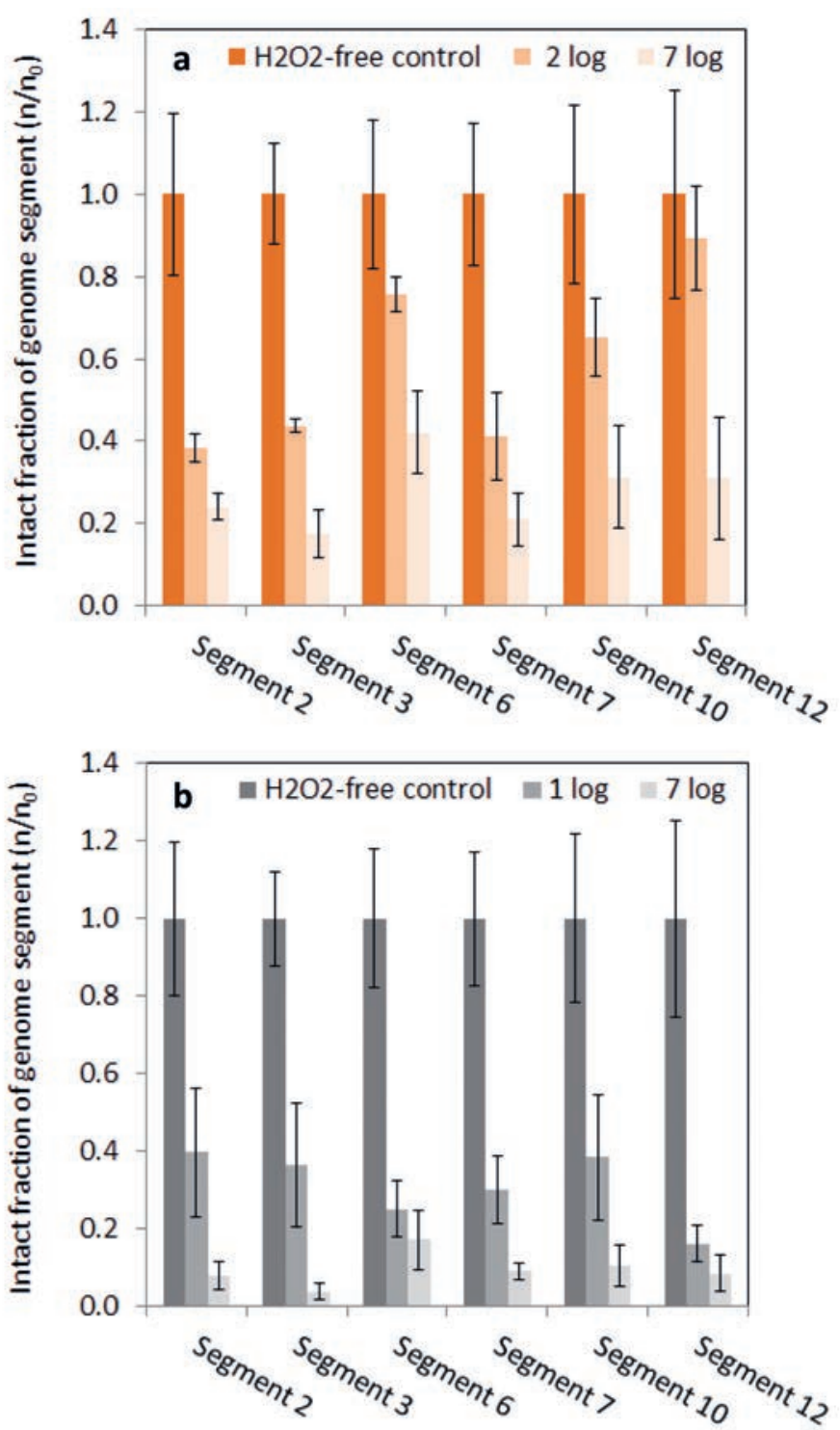

Fig. 3. Extent of degradation of different MS2 genome segments at different levels of inactivation in a) the $\mathrm{Cu} / \mathrm{H}_{2} \mathrm{O}_{2}$ and b) the $\mathrm{Fe} / \mathrm{H}_{2} \mathrm{O}_{2}$ /light system. The bars represent the average intact fraction of the respective genome segment measured in triplicate experiments, and the error bars indicate the associated standard deviation. Segment numbering corresponds to that in Pecson et al..$^{[17]}$

genome and protein degradation. The results demonstrate that, while both systems tested efficiently inactivated MS2, important differences exist in both kinetics and inactivation mechanisms.

\section{Influence of Metal Catalyst on MS2 Inactivation}

At the same metal and peroxide concentration, MS2 was inactivated more rapidly in the $\mathrm{Cu} / \mathrm{H}_{2} \mathrm{O}_{2}$ system (Fig. 2). This is particularly interesting given the fact that the production rate of hydroxyl radicals, the main oxidant in both treatment systems, was greater in the $\mathrm{Fe} / \mathrm{H}_{2} \mathrm{O}_{2}$ /light system. ${ }^{[9]}$ This finding provides an indication that the metal catalyst involved in oxidant production plays a crucial role. We have previously demonstrated that under our experimental conditions, $\mathrm{HO}^{\bullet}$ is mainly produced from dissolved $\mathrm{Cu}$ (II) species in the $\mathrm{Cu} / \mathrm{H}_{2} \mathrm{O}_{2}$ system, and from colloidal particles in the $\mathrm{Fe} / \mathrm{H}_{2} \mathrm{O}_{2}$ /light system. We have furthermore shown that the metal catalyst, and hence the site of oxidant production, must be in close vicinity to the virion to effectively cause inactivation. ${ }^{[9]}$ The small size of the dissolved $\mathrm{Cu}$ (II) likely allows a denser coverage of the viron with metal catalyst compared to the larger Fe colloids. This spatially distinct arrangement of the site of oxidant production in the two systems investigated (illus-
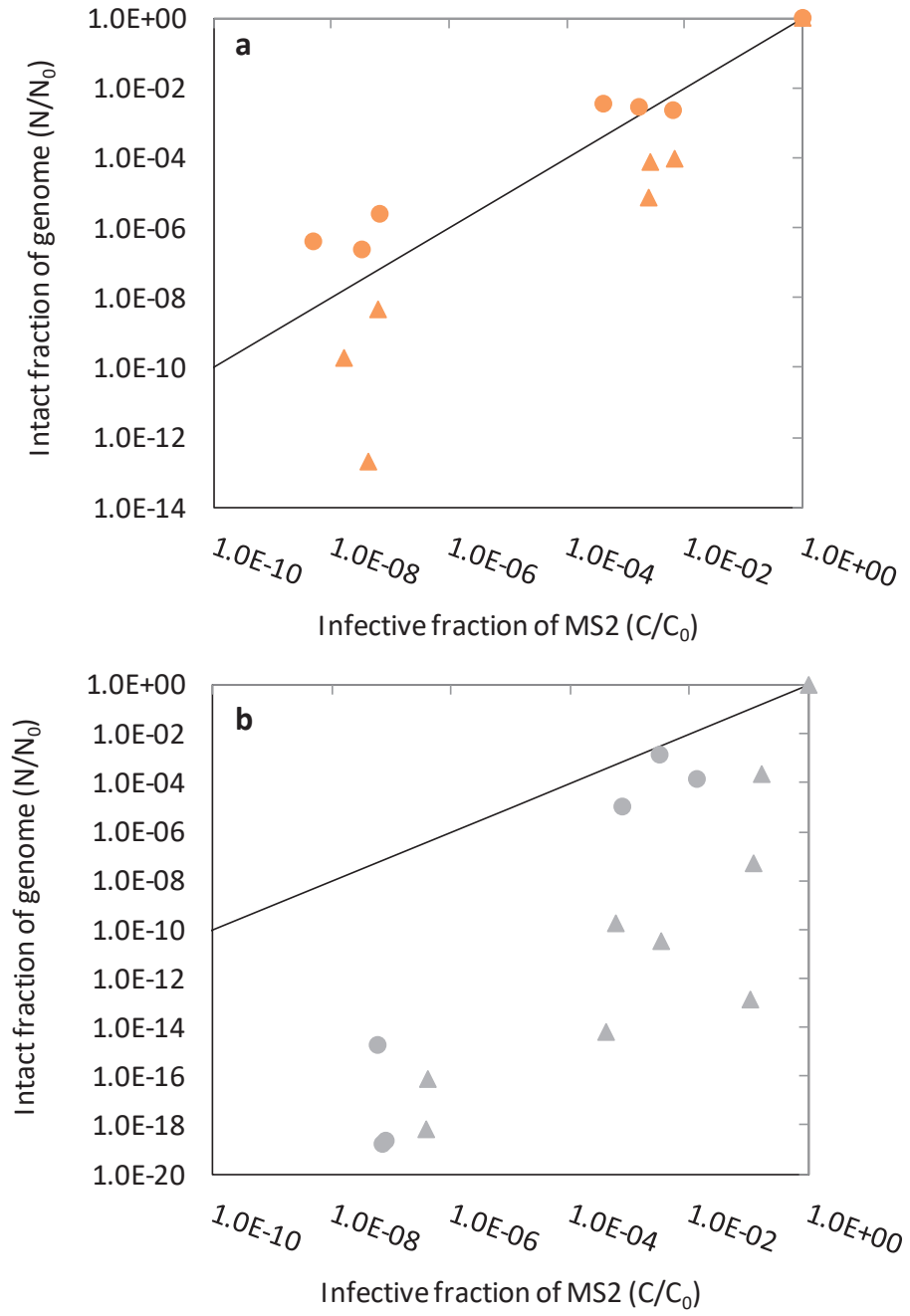

Fig. 4. Comparison of the residual fractions of intact genomes $\left(\mathrm{N} / \mathrm{N}_{\mathrm{o}}\right)$ and infective virus $\left(\mathrm{C} / \mathrm{C}_{0}\right)$ for a) the $\mathrm{Cu} / \mathrm{H}_{2} \mathrm{O}_{2}$ and b) the $\mathrm{Fe} / \mathrm{H}_{2} \mathrm{O}_{2}$ /light system. Different symbols indicate replicate experiments performed on two separate days. The solid line indicates a 1:1 relation between $\mathrm{N} / \mathrm{N}_{0}$ and $\mathrm{C} / \mathrm{C}_{0}$.

trated in Fig. 1) may influence the extent and pattern of genome and protein degradation induced by the oxidants produced, and may ultimately account for the more efficient inactivation in the $\mathrm{Cu} / \mathrm{H}_{2} \mathrm{O}_{2}$ system. The effect of the metal catalyst on genome and protein degradation is discussed below.

\section{Contribution of Genome Damage to Inactivation}

By quantifying the degradation of different genome segments, as well as of the whole genome, as a function of inactivation, several aspects regarding the mechanism of virus inactivation upon treatment by Fenton-like processes could be addressed. Specifically, we could assess 1) if inactivation by these Fentonlike leads to genome damage; 2) if damage is homogeneously distributed across the entire genome or selectively degrades particular genome regions; and 3) if genome damage is sufficiently extensive to account for the entire observed inactivation.

Inactivation was accompanied by significant genome damage (Fig. 3). The most affected genome segment in both systems was the located near 5 '-end of the genome (segment 2), indicating the 5'-end of the genome was more susceptible to attack by the oxidants than segments in the center and at the 3'-end. The distribution of genome damage is thus not a random process, and it is influenced by the genome structure but not the metal catalyst.

While the distribution of damage was similar in the two systems tested, the extent of genome damage differed, with the $\mathrm{Fe} /$ $\mathrm{H}_{2} \mathrm{O}_{2}$ /light system inducing more extensive genome degradation per unit inactivation than the $\mathrm{Cu} / \mathrm{H}_{2} \mathrm{O}_{2}$ system (Fig. 4). The 1:1 


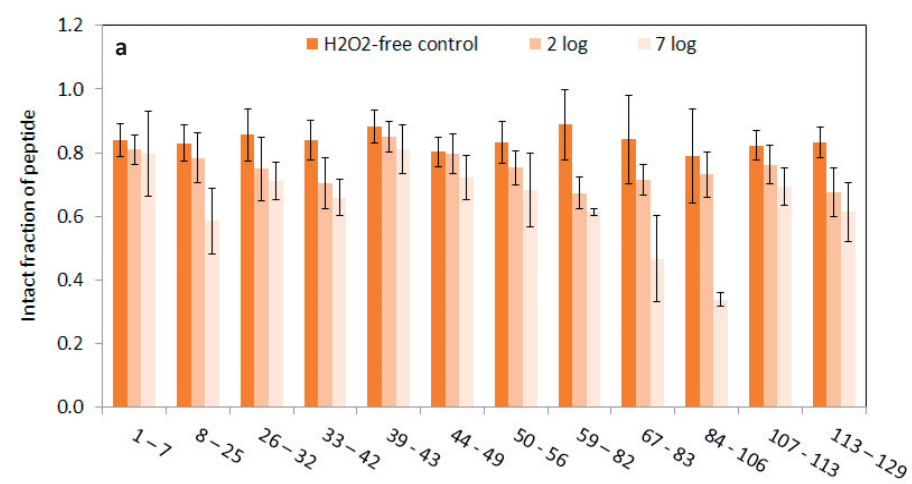

Peptide in MS2 capsid protein

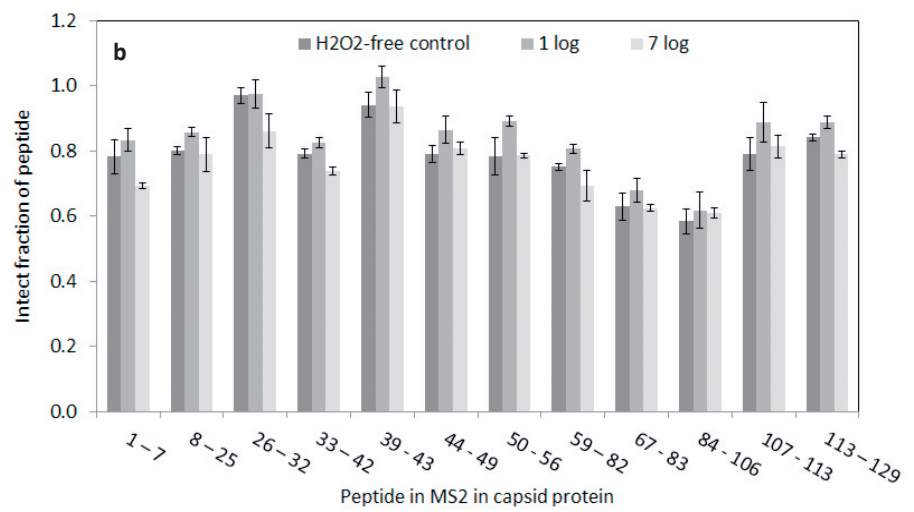

Fig. 5. Damage of the individual peptides of the MS2 capsid protein at different levels of inactivation in a) the $\mathrm{Cu} / \mathrm{H}_{2} \mathrm{O}_{2}$ system and b) the $\mathrm{Fe} /$ $\mathrm{H}_{2} \mathrm{O}_{2}$ /light system. The bars represent the average intact fraction of a given peptide measured in triplicate experiments, and the error bars indicate the associated standard deviation. Numbers indicate the amino acid residues that compose the peptide.

relation between genome damage and inactivation observed in the $\mathrm{Cu} / \mathrm{H}_{2} \mathrm{O}_{2}$ system is consistent with MS2 being inactivated by single-hit lesions to the genome. However, genome damage herein was quantified by qPCR, whereas it is not clear if each lesion detected by qPCR also causes MS2 inactivation. In fact, several studies have demonstrated that tandem and clustered lesions are responsible for genome modifications (ref. [21] and references therein). Thus, even though a 1:1 ratio between loss of genome integrity and inactivation was observed, we can nevertheless assume that genome damage alone was not sufficient to account for the inactivation of $\mathrm{MS} 2$ in the $\mathrm{Cu} / \mathrm{H}_{2} \mathrm{O}_{2}$ system. Instead, protein damage may also play an important role in inactivation.

In the $\mathrm{Fe} / \mathrm{H}_{2} \mathrm{O}_{2}$ /light system, genome damage exceeded the extent of inactivation, indicative of multi-hit kinetics. This finding confirms that not every qPCR-detectable lesion causes inactivation. The greater extent of genome degradation per unit of inactivation compared to the $\mathrm{Cu} / \mathrm{H}_{2} \mathrm{O}_{2}$ system indicates that oxidants produced in the $\mathrm{Fe} / \mathrm{H}_{2} \mathrm{O}_{2}$ /light system had an enhanced accessibility to the genome. A possible explanation for this finding lies in the ability of iron (hydr)oxides to denature proteins. ${ }^{[22]}$ It is thus conceivable that the iron colloids formed in this experimental system denatured the capsid proteins and thereby liberated the viral RNA, exposing it to oxidants (Fig. 1).

\section{Contribution of Capsid Protein Damage to Inactivation}

In contrast to genome damage, the pattern of capsid damage differed between the two systems. In the $\mathrm{Cu} / \mathrm{H}_{2} \mathrm{O}_{2}$ system, the degradation of individual peptides was more extensive and heterogeneous than in the $\mathrm{Fe} / \mathrm{H}_{2} \mathrm{O}_{2} /$ light system, where protein degradation was minimal (Fig. 6). This finding may be rationalized by two considerations. First, the two transition metals differ in their interactions with proteins. For example, albumin was found to bind $\mathrm{Cu}$ more strongly than $\mathrm{Fe}$, which resulted in site-specific oxidation in the $\mathrm{Cu}$-based Fenton-like system, and non-specific oxidation in the Fe-based system. ${ }^{[23]}$ Second, as stated above and illustrated in Fig. 1, the catalyst for oxidant production in the $\mathrm{Cu} /$ $\mathrm{H}_{2} \mathrm{O}_{2}$ system is dissolved $\mathrm{Cu}$ (II) species, whereas they are in colloidal form in the $\mathrm{Fe} / \mathrm{H}_{2} \mathrm{O}_{2} /$ light system. ${ }^{[9]}$ Given the difference in size of the two types of catalysts, the virion can likely accommodate more $\mathrm{Cu}$ ions than $\mathrm{Fe}$ colloids, leading to fewer sites of oxidant production in the $\mathrm{Fe} / \mathrm{H}_{2} \mathrm{O}_{2} /$ light system and hence less effective protein degradation.

While all peptides were affected by oxidants produced in the $\mathrm{Cu} / \mathrm{H}_{2} \mathrm{O}_{2}$ system, peptide $84-106$ was most extensively degraded (Fig. 5a). This peptide has also been found to be readily degraded by other oxidants. ${ }^{[18,24,25]}$ The crystal structure of the capsid protein indicates that several residues of this peptide are located on the outer surface of the viral capsid, ${ }^{[26]}$ and are thus readily solvent-accessible. In contrast, other portions of the capsid, which are also solvent-exposed, were degraded less efficiently. This suggests that the composition of the segment plays a role in its propensity to degrade. This is in agreement with previous work which has shown that both the location of a segment and its amino acid composition govern its susceptibility to oxidation. ${ }^{[27,28]}$ In particular, the sulfur-containing residues methionine and cysteine are prone to degradation by Fenton-like processes. ${ }^{[29,30]}$ Segment 84-106 contains two sulfur-bearing amino acids, namely a methionine (Met88) and a cysteine (Cys101), which may account for its propensity to degrade in the presence of oxidants. Other sulfur-containing residues (e.g. Cys46 in segment 44-49), which were less solvent-accessible, were less susceptible to degradation. Overall, it can be concluded that oxidants generated in the $\mathrm{Cu}$ / $\mathrm{H}_{2} \mathrm{O}_{2}$ system can attack the entire capsid protein, though protein regions that are solvent-exposed and contain easily oxidizable residues are the most affected. It is not known, however, if the degradation of these regions directly contributes to loss of virus infectivity.

In summary, our results demonstrate virus inactivation in different Fenton-like systems can differ with respect to both inactivation kinetics and mechanisms, and is closely linked to the aqueous chemistry of the transition metal catalyst. Specifically, the solubility and resulting spatial arrangement of the catalyst around the virion, and hence the site oxidant production, likely determine the disinfection outcome. In the $\mathrm{Cu} / \mathrm{H}_{2} \mathrm{O}_{2}$ system, $\mathrm{HO}^{\bullet}$ was produced by dissolved $\mathrm{Cu}$ ions, which can readily access the virion. The resulting inactivation was rapid and involved the degradation of both viral genome and proteins. In the $\mathrm{Fe} \mathrm{H}_{2} \mathrm{O}_{2}$ /light system, in contrast, $\mathrm{HO}^{\bullet}$ was produced by iron colloids, which are likely positioned at a greater distance to the virion surface and are thus are less effective at oxidizing the viral proteins. Instead,
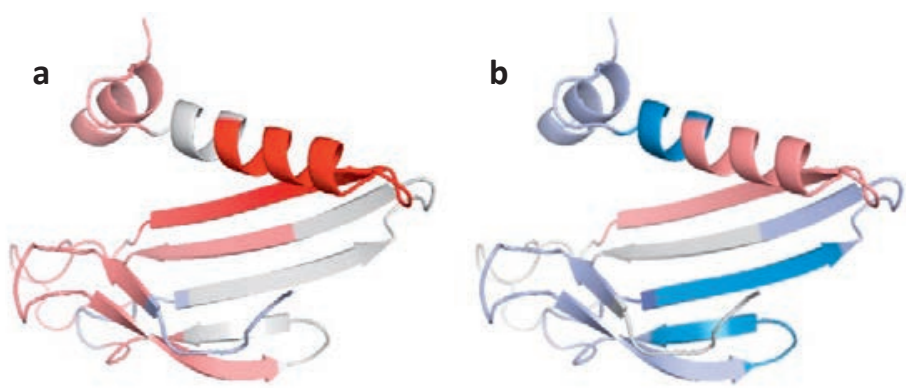

Intact fraction

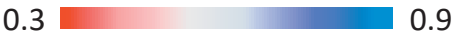

Fig. 6. Illustration of the extent of degradation of the different regions of the MS2 capsid protein after 7 log of inactivation in a) the $\mathrm{Cu} / \mathrm{H}_{2} \mathrm{O}_{2}$ system and b) the $\mathrm{Fe} / \mathrm{H}_{2} \mathrm{O}_{2}$ /light system. Red color indicates extensively degraded regions; blue color indicates weakly degraded regions. Peptides and extent of degradation correspond to those shown in Fig. 5. Images were created in pymol, using on PDB file 1MSC. 
the iron colloids may have denatured the protein and exposed the RNA. The resulting inactivation occurred at a slower rate, and involved solely genome damage. The dissolved or colloidal state of the catalyst should be considered when applying Fenton-like processes to virus disinfection. This is particularly important for viruses which are resistant to genome-degrading disinfectants (e.g. adenovirus), due to their ability to use the host's genome repair systems. For these viruses, a dissolved metal catalyst that promotes both genome and protein damage should be considered.

\section{Acknowledgements}

This research was funded by Swiss National Science Foundation (Projects No. 200021_118077 and 200020_131918). The authors thank Thérèse Sigstam and Loic Decrey for performing the MALDI-TOF-MS measurements.

\section{Conflict of Interest}

No conflict of interest declared.

Received: October 1, 2019

[1] I. García-Fernández, M. I. Polo-López, I. Oller, P. Fernández-Ibáñez, Appl. Catal. B Environ. 2012, 121-122, 20, DOI: 10.1016/j.apcatb.2012.03.012.

[2] D. Spuhler, J. Andrés Rengifo-Herrera, C. Pulgarin, Appl. Catal. B Environ. 2010, 96, 126, DOI: 10.1016/j.apcatb.2010.02.010.

[3] E. Ortega-Gómez, P. Fernández-Ibáñez, M. M. Ballesteros Martín, M. I. Polo-López, B. Esteban García, J. A. Sánchez Pérez, Water Res. 2012, 46, 6154, DOI: 10.1016/j.watres.2012.09.007.

[4] A.-G. Rincón, C. Pulgarin, Appl. Catal. B Environ. 2006, 63, 222, DOI: 10.1016/J.APCATB.2005.10.009.

[5] J. L. Sagripanti, L. B. Routson, C. D. Lytle, Appl. Environ. Microbiol. 1993, $59,4374$.

[6] J. L. Sagripanti, Appl. Environ. Microbiol. 1992, 58, 3157.

[7] C. Ruales-Lonfat, J. F. Barona, A. Sienkiewicz, M. Bensimon, J. VélezColmenares, N. Benítez, C. Pulgarín, Appl. Catal. B Environ. 2015, 166 167, 497, DOI: 10.1016/J.APCATB.2014.12.007.

[8] J. I. Nieto-Juarez, T. Kohn, Photochem. Photobiol. Sci. 2013, 12, 1596, DOI $10.1039 / \mathrm{c} 3 \mathrm{pp} 25314 \mathrm{~g}$.

[9] J. I. Nieto-Juarez, K. Pierzchła, A. Sienkiewicz, T. Kohn, Environ. Sci Technol. 2010, 44, 3351.

[10] N. Yamamoto, Virology 1969, 38, 457, DOI: 10.1016/0042-6822(69)901585 .

[11] N. Yamamoto, C. W. Hiatt, W. Haller, Biochim. Biophys. Acta - Spec. Sect. Nucleic Acids Relat. Subj. 1964, 91, 257, DOI: 10.1016/09266550(64)90249-X.

[12] J. Y. Kim, C. Lee, D. L. Sedlak, J. Yoon, K. L. Nelson, Water Res. 2010, 44 2647, DOI: 10.1016/j.watres.2010.01.025.

[13] K. J. Davies, M. E. Delsignore, S. W. Lin, J. Biol. Chem. 1987, 262, 9902.
[14] M. Dizdaroglu, P. Jaruga, Free Radic. Res. 2012, 46, 382, DOI: 10.3109/10715762.2011.653969.

[15] N. Kashige, Y. Kakita, Y. Nakashima, F. Miake, K. Watanabe, Curr. Microbiol. 2001, 42, 184, DOI: 10.1007/s002840010201.

[16] S.Lee, M. Nakamura, S. Ohgaki,J.Environ. Sci. Heal. - PartAToxic/Hazardous Subst. Environ. Eng. 1998, 11, 1643, DOI: 10.1080/10934529809376809.

[17] B. M. Pecson, L. V Martin, T. Kohn, Appl. Environ. Microbiol. 2009, 75 , 5544, DOI: 10.1128/aem.00425-09.

[18] K. R. Wigginton, B. M. Pecson, T. Sigstam, F. Bosshard, T. Kohn, Environ. Sci. Technol. 2012, 46, 12069, DOI: 10.1021/es3029473.

[19] M. J. Mattle, B. Crouzy, M. Brennecke, K. R. Wigginton, P. Perona, T. Kohn, Environ. Sci. Technol. 2011, 45, 7710, DOI: 10.1021/es201633s.

[20] B. M. Pecson, M. Ackermann, T. Kohn, Environ. Sci. Technol. 2011, 45, 2257, DOI: $10.1021 / \mathrm{es} 103488 \mathrm{e}$.

[21] J. Cadet, T. Douki, J.-L. Ravanat, in 'Studies on Experimental Models', Humana Press, Totowa, NJ, 2011, pp. 579, DOI: 10.1007/978-1-60761-956729.

[22] F. Liu, X. Li, A. Sheng, J. Shang, Z. Wang, J. Liu, Environ. Sci. Technol. 2019, 53, 10157, DOI: 10.1021/acs.est.9b02651.

[23] T. Kocha, M. Yamaguchi, H. Ohtaki, T. Fukuda, T. Aoyagi, Biochim. Biophys. Acta - Protein Struct. Mol. Enzymol. 1997, 1337, 319, DOI: 10.1016/S01674838(96)00180-X.

[24] K. R. Wigginton, L. Menin, J. P. Montoya, T. Kohn, Environ. Sci. Technol. 2010, 44, 5437, DOI: 10.1021/es100435a.

[25] L. Hu, M. A. Page, T. Sigstam, T. Kohn, B. J. Mariñas, T. J. Strathmann, Environ. Sci. Technol. 2012, 46, 12079, DOI: 10.1021/es3031962.

[26] K. Valegård, L. Liljas, K. Fridborg, T. Unge, Nature 1990, 345, 36, DOI: $10.1038 / 345036 \mathrm{a} 0$.

[27] E. M. Hotze, A. R. Badireddy, S. Chellam, M. R. Wiesner, Environ. Sci. Technol. 2009, 43, 6639.

[28] T. Sigstam, G. Gannon, M. Cascella, B. M. Pecson, K. R. Wigginton, T. Kohn, Appl. Environ. Microbiol. 2013, 79, DOI: 10.1128/AEM.00663-13.

[29] E. R. Stadtman, R. L. Levine, Amino Acids 2003, 25, 207, DOI: 10.1007/ S00726-003-0011-2

[30] B. S. Berlett, E. R. Stadtman, J. Biol. Chem. 1997, 272, 20313, DOI: 10.1074/jbc.272.33.20313.

\section{License and Terms}

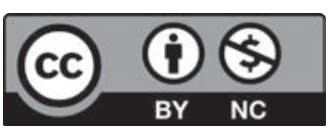

This is an Open Access article under the terms of the Creative Commons Attribution License CC BY_NC 4.0. The material may not be used for commercial purposes.

The license is subject to the CHIMIA terms and conditions: (http:// chimia.ch/component/sppagebuilder/?view=page \&id=12).

The definitive version of this article is the electronic one that can be found at doi:10.2533/chimia.2020.149 